\title{
Research on the Implementation of Happy Teaching in Film and Television Professional Courses of College
}

\author{
Yuelin Hu \\ Department of Film and Television Arts, Shanghai Publishing and Printing College, Shanghai, China \\ Email: 271038044@qq.com
}

How to cite this paper: Hu, Y. L. (2020). Research on the Implementation of Happy Teaching in Film and Television Professional Courses of College. Creative Education, 11, 321-327

https://doi.org/10.4236/ce.2020.113025

Received: February 12, 2020

Accepted: March 14, 2020

Published: March 17, 2020

Copyright $\odot 2020$ by author(s) and Scientific Research Publishing Inc. This work is licensed under the Creative Commons Attribution International License (CC BY 4.0).

http://creativecommons.org/licenses/by/4.0/

\begin{abstract}
The use of happy teaching in classroom teaching is the reform direction of film and television professional teaching. How to implement happy teaching on the film and television major in college is an urgent problem in the current classroom teaching of film and television courses. Therefore, this paper discusses the necessity of happy teaching, the related strategies and methods of happy teaching implementation, and combines the examples in teaching to demonstrate its feasibility, which provides a reference for the future reform of film and television professional courses.
\end{abstract}

\section{Keywords}

Happy Teaching, Film and Television Speciality, Professional Courses

\section{Research Background}

With "50 Articles" of Shanghai Cultural Creativity proposed, the demand for film and television talents has increased substantially, and also continuously improved. With the development of the film and television industry, the industry is shortage of the talents who can create, make and connect with the international market.

Now, the concept of happy teaching has been promoted in colleges and universities, but there is little research for the implementation of happy teaching on film and television professional courses. How to exert the students' independent innovation ability through happy teaching, and to improve the artistic literacy while mastering the relevant skills of film and television, is the focus of the teaching reform of the "Innovative Film Talent Cultivation Mode" in higher vocational colleges. 


\section{The Necessity of Implementing "Happy Teaching" in Higher Vocational Film and Television Professional Courses}

Happy teaching is a teaching method in which teachers bring happiness into the classroom and mobilize students' interest and enthusiasm to participate in the teaching process positively, thereby improving the teaching effect. Learning it is good, taking an interest in it is better, but enjoying it is the best. As the saying goes, "interest is the first teacher", how to stimulate students' interest in learning is the embodiment of teachers' teaching art and the source of "happy teaching". "Give a man a fish and you feed him for a day; teach a man to fish and you feed him for a lifetime." It is only be called listening the book with relish that make students to be interested in the teaching content or to create a relaxed and pleasant classroom atmosphere. While making learning itself to be an interest is the foundation of "happy teaching" by cultivating and inspiring the passion of the students in the process of classroom teaching. The enthusiasm of learning makes learning itself an interest, which is the foundation of "happy teaching."

Of the more than 100 students who received the questionnaire, $67 \%$ had absenteeism. Of these, $57 \%$ found the class tedious and too much content, and $36 \%$ said that the teaching method was traditional and not interesting.

In recent years, with the rapid development of film and television technology, colleges and universities keep pace with the times to improve experimental conditions, and focus on teaching hardware operation and software use. Therefore, the class is dominated by experiments with lack of the cultivation of innovative ability and artistic literacy, which easily causes the classroom teaching to be boring.

Otherwise, talking a lot about the film industry experience or lace news with no essential teaching content will go on the road of pan-entertainment teaching. The major courses in film and television profession include non-linear editing, photography, lighting technology, sound design, recording technology, post-production special effects, etc, with wild range of knowledge, but most of them have the characteristic of combining art and technology. While the equipment and software are only the tools of film and television art creation, the new life and development of art rely on innovation. When conducting specific teaching, teachers can't have the order reversed, and not only teach technical skills, but also help students accumulate materials, broaden their field of vision and thinking.

In terms of teaching environment, although many colleges and universities have advanced film and television experimental training rooms, they still can't escape the traditional classroom teaching mode mainly based on that teachers make lectures and after that students follow the example of practice with the assistance of multimedia coursewares, video and teaching resource website. This generation of students who grow up in the context of the new media era contact a variety of media forms, rich access to information, and have high sensitivity to new things. So they are more inclined to visual and vivid form when accepting 
information. In addition, art students are more prominent in personality, who are eager to get free stage and space where they can show. While the participation is low in the traditional classroom, the fun and enthusiasm of students in classroom learning is lost.

Herbert Spencer, the presenter of happy teaching, said: "The best education in the world is inherently happy." He also emphasizes that painful learning can be disgusting, while happy learning make knowledge can be attractive. In the same situation, the efficiency of teaching is in direct proportional with the degree of happiness students get when studying (Han, Han, Xiong, Wang, \& Xiao, 2018). Meanwhile, happy teaching is a method that has been widely praised by the education industry in recent years to effectively improve the study enthusiasm, which also is effective for the teaching of film and television profession. Therefore, in order to reduce students' studying weariness, establish a harmonious relationship between teachers and students, and create harmony classroom atmosphere, it is essential that helping students to promote their comprehensive development of knowledge, skills and literacy through internalizing knowledge and skills based on their cognitive structure by using "happy teaching" (Huang, 2018).

\section{The Implementation Strategy and Method of "Happy Teaching"}

\subsection{Integration of PRODUCTION and Education: Improving the Quality of "Happy Teaching"}

In the process of learning, the loss of self-realization need is the most problem students often meet. While learning is also a process of self-value realization. Traditional classroom teaching is difficult for students to achieve self-worth, because individual difference cannot be considered in instilling curricular teaching, which is the reason why students are tired of learning ( $\mathrm{Li} \& \mathrm{Lv}, 2013)$. Therefore, teachers should provide students with platforms to display their talents so as to promote their comprehensive and individual development before students' motivation of learning is stimulated.

The combination of production and education is the integration of education and different social divisions of production in terms of functions and resource advantages, of which main implementation method is to combine the learning achievements of students directly with social practice instead of classroom testing.

The sense of accomplishment is a kind of happiness, which comes from achieving to perfection step by step. The combination of production, study and research is a "happy teaching" strategy that makes students feel happy by helping them win the sense of accomplishment, because project practice of each time for students goes to be successful by the way of constant accumulation, precipitation, and attempt, which can fully mobilize the enthusiasm of teachers and students in teaching and learning, so that students can gain a great sense of accom- 
plishment and self-identity.

The teaching mode of the multi-subject integration and and combination of production and education have been emerged in an environment of vigorously promoting the reform of "double innovation" education, which effectively improve students' practical ability and innovative spirit ( $\mathrm{Du}, 2011)$. Graduation design mode of combining production, study and research is an effective training model for improving the quality of graduation design and solving the problem of separating theory with practice in graduation design teaching, which is complementary and organically integrated with each other. Thus, when it is implemented for graduation design teaching, the mode not only can well bridge the relationship between industry, education and research, and fully mobilize the enthusiasm of teachers and students, but also a good way to comprehensively test the various skills that students learn during the three years of study. Every piece of graduation design is born in constantly accumulating, precipitating, and trying.

\subsection{Second Classroom: Expansion of "Happy Teaching" Space}

The second strategy of happy teaching strategy is Second Classroom. Second Classroom belongs to the category of classroom teaching. If, according to the textbook and the syllabus, the classroom teaching activities carried out during the prescribed teaching time are called the first classroom, then the second classroom refers to the teaching activities related to the first classroom at the time outside the first classroom (Ling, 2008). From the teaching content, it is derived from the textbook and is not limited to the textbook; it does not require an exam, but it is also an indispensable part of quality education. Formally, it is lively and colorful.

In terms of time and space, "Second Classroom" is the extension of First Classroom, which provides wider and more abundant space and time, makes teaching content break through the constraints of time and space, provides richer imagination platform for teachers and enriches teaching content. But there are several misunderstandings in understanding of "Second Classroom". First, Second Classroom is off-campus practice activities. Actually, it has large wide learning space. It can not only be implemented out of the campus, like in the society or families, but also be implemented in the campus, like classrooms and playgrounds. Thus, the Second Classroom we understand shall not be limited to "off campus". The club, studio and so on in the campus that related with the content of the First Classroom can all be called "Second Classroom"; Second, post practice is equal to "Second Classroom". To distinguish the two concepts, first, there should be a correct understanding of the "classroom". The "classroom" is a kind of period with structure, during which, students learn knowledge, and teachers or tutors teach at least one student, even more. It plays roles of evaluation, interaction between teachers and students, encouragement and summary. Thus, the post practice lack of interaction between teachers and students cannot be called "Second Classroom", and the "Second Classroom" cannot 
be separated from the syllabus, which is different from integration of industry and education.

The "Second Classroom" can be carried out through visiting exhibitions, theatres or museums and other art places. Especially those courses related with art history, because of its historical limitation in the light of content of teaching material as well as the limit to the length of the textbook, visiting art places not only can make students have a close look at the famous works so as to achieve a more specific and detailed understanding of the teaching content involved in "the first classroom", but also can have both ancient and modern learning and inspire artistic creation while immersed in the artistic atmosphere.

Except visits or field visits, "Second Classroom" may also appear in the way of practical exploration. Students need to do it by themselves to get real knowledge in practice so as to better understand the content of the lesson and feel the fun of hands-on practice, which is helpful for the cultivation and improvement of students' artistic accomplishment and professional quality.

"Second Classroom" is an important part of "happy teaching", an important platform for teaching and entertainment, and an education mode that makes students give full play to their potential. It can effectively promote students' cooperative learning and build a harmonious interpersonal relationship. It can stimulate learning enthusiasm and wisdom. Students' innovative thinking is also easier to be inspired. It can also reflect teachers' unique charm in talent training.

\subsection{Information Technology: Enrich the Means of "Happy Teaching"}

Under the guidance of the guidelines of the Ten-Year Development Plan of Educational Informatization (2011-2020), the establishment of information teaching in higher education continues to develop deeply in the college teaching and other aspects. The application of information technology in the teaching becomes the focus of scholars. To teach based on information, first, can strengthen the communication between teachers and students so as to enhance emotion and avoid "learning weariness" and "teacher weariness". Time for classroom teaching is limited and it is hard to build friendship between teachers and students in such a short time. Moreover, classroom teaching is generally based on teachers' teaching and it is hard for students to feedback timely. Thus, besides classroom teaching, teachers can keep communicating with students at all times with Wechat, QQ, microblog and other social media. Students can contact with teachers in the way they are most used to when they encounter learning difficulties. When students and teachers use the same chatting software, they become closer, which can make students relax themselves when communicating with teachers. This mode is widely used in current teaching and achieves very good results.

Second, information teaching can meet the students' demand of "everyone becomes a talent and learns forever". The Outline of National Medium- and Long-Term Education Reform and Development Plan (2010-2020) clearly puts 
forward that the education should build the cultivation concept that everyone can be a talent. This concept fully respects the dominant role of students, which is not only the ideal of students and parents, but also the need of the development of higher vocational film and television education. In addition, the students of this generation grow up in the era of rapid development of information technique and they are proficient in using information equipment. Thus, it is the requirement of future learners to use information technology for lifelong learning in the era of big data. The classroom time limits the teaching content, but the development of the film and television industry varies from minute to minute. In order to make students keep pace with the era and understand the latest film and television production methods and skills, the information teaching mode must be relied on. In teaching content, the information teaching provides a lot of open network mobile courses and can realize real-time update so as to effectively help students construct their own knowledge systems through massive learning materials; in teaching environment, it is not necessary to rely on traditional multimedia teaching equipment, such as, computers, projectors, audio and video equipment, etc, and they can directly log in on their Smartphone which is easy to carry; in teaching evaluation, it can record the learning state of students in real time objectively and feedback and evaluate timely, so as to help students make individualized teaching plan and satisfy the learning demands of different stages and levels. For example, our college built a mobile course APP integrating film and television courses, which involves the operation of many hardware and software equipment. However, students have limited time in the class and it is hard for them to master some techniques in class. Thus, in the era of pure classroom teaching, some students will give up learning while they cannot keep up with and there will be vicious circle of "weariness of learning". Nowadays, students can watch relevant mobile courses repeatedly after class while they didn't master what they learned in the class. And students' interest and enthusiasm in learning were significantly improved.

\section{Matters Needing Attention during Implementation}

\subsection{Teaching Content Shall Be Reasonable}

During the implementation, don't adopt a cramming education which makes the class stiff and boring. The film and television courses are both theoretical and practical. It is hard for students to concentrate on monotonous theory teaching, precisely receive the teaching signal of teachers and master and apply complex film and television skills. Thus, reasonable teaching content is needed to arouse the interest of students.

\subsection{Personality Characteristics of Students Shall Be Considered}

During the implementation of happy teaching, teachers shall fully consider the personality characteristics of students and the vocational characteristics of film and television industry. Due to the difference of students' hands-on ability and 
understanding ability, when carrying out the actual operation, some students are quick to learn while some are hard to master the professional knowledge totally. If teachers fail to give considerations to the both sides, "one-size-fits-all" will affect the teaching progress and reduce the teaching efficiency.

\subsection{Evaluate Students' Results through the Way of Practical Ability Evaluation}

The level of film and television specialty cannot be reflected totally in the test paper. Thus, it is one-sided and unreasonable to measure the professional ability of film and television students through the final exam. It is easy to make students develop the habit of learning by rote so as not to master the essence of knowledge, which also violates the original intention of happy teaching. Thus, it is recommended to evaluate students' ability by practical ability evaluation.

\section{Conclusion}

Practice has proved that to use happy teaching in the education is the direction of the current teaching and education reform of film and television specialty in higher vocational education. It can effectively improve the teaching level of film and television specialty in higher vocational education and is confirmed by the students and society, which provides some reference for the future teaching and education reform of film and television specialty in higher vocational education.

\section{Conflicts of Interest}

The author declares no conflicts of interest regarding the publication of this paper.

\section{References}

Du, L. (2011). A Study on Happy Classroom Teaching in Colleges and Universities Based on Systematic Viewpoint. Education and Teaching Forum, No. 26, 9-11.

Han, X. C., Xiong, Y., Wang, X. M., \& Xiao, C. Q. (2018). Discussion on the Teaching Reform of Happy Classroom Teaching in Colleges and Universities under the Background of "Double First-Class". Research on Curriculum Education, No. 33, 231-232.

Huang, Y. J. (2018). Discussion on the Application of Happy Teaching in College Basketball Teaching. Journal of Heihe University, No. 7, 114-115.

Li, J. H., \& Lv, G. (2013). My Opinion on College Physical Education Based on the Concept of Happy Teaching. Heihe University, No. 10, 87.

Ling, D. Z. (2008). On "Happy" Teaching of Ideological and Political Theory Course in Colleges and Universities. China Higher Medical Education, No. 10, 54, 92. 